\author{
Agnieszka Mierzwińska-Hajnos \\ Maria Curie-Skłodowska University \\ Plac Marii Curie-Skłodowskiej 5, \\ 20-031 Lublin, Poland
}

\title{
Shockvertising: Beyond Blunt Slogans and Drastic Images. A Conceptual Blending Analysis
}

\begin{abstract}
The present paper discusses the application of Conceptual Blending Theory (henceforth: CBT) as proposed by Fauconnier and Turner (cf. Fauconnier and Turner 1998, 2002) to the analysis of shockvertising that appears in social campaigns. Assuming that the main objective of the so-called shockvertising is to startle the audience and thus draw their attention to the most burning social problems, usually overlooked when presented in the form of typical posters, CBT proves a successful tool in decoding messages comprised in such ads. Of particular importance is a conceptual blend which dynamically emerges as a result of various blending processes activated while decoding both visual and verbal components recalled in shock advertisements.
\end{abstract}

1. Introduction

Conceptual blending (henceforth: CB) as developed by Gilles Fauconnier and Mark Turner (Fauconnier and Turner 1998, 2002, Fauconnier 2010) is a dynamic process that frequently occurs at the moment of perception to create new meanings from already existing ways of thinking (cf. Joy et al. 2009). Since the creativity and potential that reside in thought and language "depend on our capacity 
to manipulate webs of mappings between mental spaces" (Fauconnier 1997: 149), conceptual blends frequently occur both in verbal and visual domains, such as those thoroughly exploited in advertising. According to McQuarrie and Mick, "visual images and verbal messages constitute culturally embedded forms or signs that combine in a specific manner to communicate meanings about brands" (see Joy et al. 2009: 39). Therefore, the task of Fauconnier and Turner's Conceptual Blending Theory is to account for the processes which facilitate reading the message hidden in various types of advertisements (cf. Nühnen 2010).

This paper discusses the nature of a conceptual blend that occurred in a social campaign for Organ Donor Foundation, with the aid of Conceptual Blending Theory as proposed by Fauconnier and Turner. Since the main goal of shock advertising ( $a k a$ shockvertising) is, first and foremost, to capture the attention of the audience, create a feeling of excitement as well as raise people's awareness to important issues, e.g. health care, domestic violence, or smoking, copywriters responsible for creating such shock advertisements strive to provoke a potential recipient of the information by violating the already existing conventional understanding of the social order, expressed via controversial or disturbing images, and, frequently, thought-provoking verbal messages.

Still, the role of a successful shock advertisement is not only to attract the viewers' attention by exposing them to violent images or blunt slogans. Shockvertising should also comply with the parameters typical of a successful ad, i.e. it should have attention value, be 'readable', 'memorable' and have 'selling power' (cf. Leech 1972). For this reason, analyzing social advertisements from a cognitive perspective, in particular applying the blending theory, becomes even more intriguing and challenging. The proposed paper discusses the way we arrive at the actual meaning of a shock ad for Organ Donor Foundation, using our cognitive capacity. The advertisement is analyzed adopting a conceptual blending perspective. It is going to be proved that the emergent meaning being the result of dynamic blending processes not only meets the requirement of a thought- 
provoking shock advertisement but, first and foremost, portrays the phenomenon of blending as a fundamentally conceptual mechanism that accounts for intricate nuances of 'mind's hidden complexities' (Fauconnier and Turner 2002).

\section{On shockvertising}

Shock advertising, more frequently known as shockvertising, is a relatively recent and revolutionary type of advertising based on eyecatching graphics, unwonted slogans and pictures, whose main objective is to "deliberately, rather than inadvertently startle and offend [the] audience by violating norms for social values and personal ideas" (Dahl et al. 2003: 268). Another definition of shockvertising is delivered by Belch and Belch, describing the phenomenon as a genre whose pivotal role is to "elicit attention for a brand name by jolting consumers" (Belch and Belch 1998:7).

The notion of shockvertising is mainly associated with Oliviero Toscani, the author, photographer and creative director of the Benetton company, famous for his controversial advertising campaigns, where voyeurism, shock and sensationalism became the principles of their effectiveness, almost to the detriment of "separating the advert from the product" (Falk 1997: 72, after Sandikçi 2011: 44). ${ }^{1}$ The basic characteristics of shock advertisements are "provocative images of human suffering and misery as well as through images that are erotic or pornographic, disgusting, vulgar, and morally insulting or mocking" (Sandikçi 2011:43). Moreover, controversial and disturbing ads instill the sense of guilt, fear or compassion in the viewer himself and, as such, should develop greater social awareness, especially with reference to the issues raised in social campaigns. Whether they become successful in this field remains disputable. Berger, for instance, claims that "the barrage of shocking and disturbing images is the best way to address difficult social issues" (Berger 2001: 307).

\footnotetext{
${ }^{1}$ The impact of Toscani's shock advertisements for Benetton products results in the phenomenon known as the Benetton-Toscani effect, which delimits the scope of conventional advertising (Falk 1997).
} 
Arnold, for a change, calls such a procedure into question indicating that the use of shock appeal usually captures a viewer's attention but there is a fine line in what people consider productive shocking and offensive to the public (Arnold 2009).

Unquestionably, shock advertisements fall under the category of general advertising in that they attempt to "inform and persuade a large number of people with a single communication" (Longman 1971: 47). What clashes with the image of a typical ad is the fact that they are rarely pleasing in appearance for the viewers. Equally, shock advertisements are infrequently created for economic purposes, but rather point to the promotion of certain ideas connected with controversial issues that affect society, although it must be admitted that the issue of whether shockvertising serves a purely economic purpose is still disputable. On the one hand, marketers use shockvertising "when the backfire is lesser than the gain" (source: www.marketingfaq.net), which seems to be confirmed by Benetton using controversial shock advertisements to boost its brand. Nevertheless, the effectiveness of such ads is dubious in popular advertising. As pointed out by Kubacka, "shockvertising aims at capturing attention of customers to a particular product and usually supports a sales strategy in the short run" (Kubacka 2012: 16, after Konieczna 2010: 6). More convincing is the idea of implementing shock advertisements in social campaigns, which was proved by Parry et al. in their thorough study upon the viewers' reactions towards shockvertising used in for-profit vs non-profit organisations, where shockvertising proved justifiable in the latter (cf. Parry et al. 2013).

The question arises to what extent shockvertising as a type of advertising might become an interesting material in linguistic analysis? Nühnen makes the following observation on that issue (Nühnen 2010: 1):

In order to always be more creative, more appealing, and more outstanding than the competition new advertising strategies have emerged. But what makes advertisement creative, interesting, outstanding? Apart from the product itself it is language and the symbols that are used to present the product. This is where the connection from advertisement to linguistics comes from. 
Adopting the above statement, let us now proceed to an in-depth analysis of the chosen shock advertisement in the light of Conceptual Blending Theory as delineated by Fauconnier and Turner.

3. Conceptual Blending Theory: basic tenets

Conceptual Blending Theory (cf. Fauconnier and Turner 1998, 2002), also known as Conceptual Integration Theory, or Many Space Model (cf. Evans 2007) is an approach developed within cognitive linguistics paradigm that points to basic mental operations occurring in the human mind during the conceptualization process. As observed by the pioneers of the theory, Gilles Fauconnier and Mark Turner (1998: 133),

Conceptual integration-blending-is a general cognitive operation on a par with analogy, recursion, mental modelling, conceptual categorization, and framing. It serves a variety of cognitive purposes. It is dynamic, supple, and active in the moment of thinking. It yields products that frequently become entrenched in conceptual structure and grammar, and it often performs new work on its previously entrenched products as inputs. Blending is easy to detect in spectacular cases but it is for the most part a routine, workaday process that escapes detection except on technical analysis. It is not reserved for special purposes (...)

Assuming that conceptual blending is a common and multi-faceted cognitive activity, Fauconnier and Turner's approach becomes a useful tool in the analysis of linguistic and non-linguistic phenomena. For this reason, the approach might prove particularly successful in the analysis of various sorts of advertisements where reading out the message conveyed in a given ad requires an immediate activation and mental connection of various experiences (Cornelissen 2006).

The Fauconnier and Turner theory derives from two traditions previously developed within cognitive semantics, i.e. Conceptual Metaphor Theory in the sense of Lakoff and Johnson (Lakoff and Johnson 1980), and Mental Spaces Theory, earlier delineated by Gilles Fauconnier himself (Fauconnier 1994) ${ }^{2}$. To successfully

${ }^{2}$ Conceptual Blending Theory is closely combined with Mental Spaces Theory in that both approaches are interrelated in terms of structure as well as basic tenets, in particular, the dynamic aspect of meaning construction. What is more, Fauconnier and 
account for how the emergent meaning arises, Fauconnier and Turner proposed a four-space integration network model in lieu of the twodomain mapping used while reading out conceptual metaphors. The model of conceptual integration is presented in Figure 1.

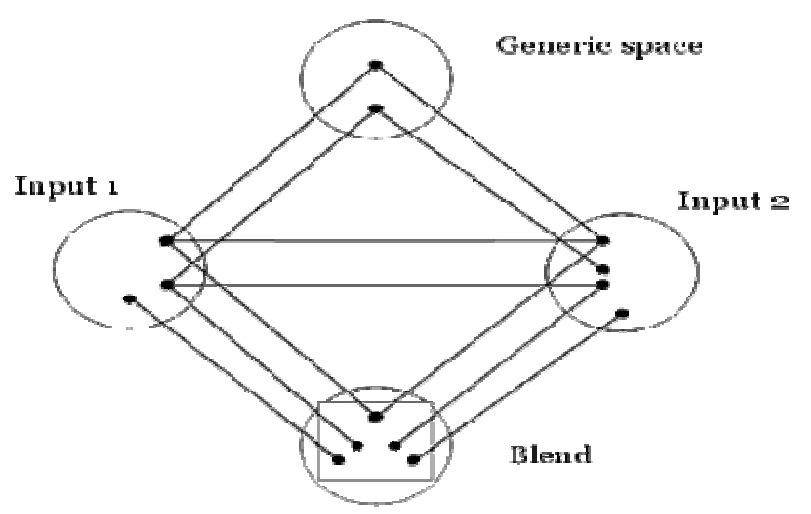

Figure 1. The basic four-space integration network (Fauconnier and Turner 2002: 46)

According to Fauconnier and Turner, the model should allow for four spaces responsible for conceptual integration, i.e. at least two input spaces, a generic space and a blended space. The elements that occur in input spaces take part in identifying cross-space counterparts

Turner's theory adopts the notion of mental spaces as well as mental space architecture as an essential element of its construction. Nevertheless, as observed by Evans (2007: 12), "blending theory adds significant theoretical sophistication of its own". As far as the contribution of Conceptual Metaphor Theory to the development of Conceptual Blending Theory is concerned, CBT resembles CMT in the following aspects: both approaches view metaphor more as a conceptual rather than linguistic phenomenon, as well as "involve systematic projection of language, imagery and inferential structure between conceptual domains" (Grady, Oakley and Coulson 1999:101). What is more, both theories impose constraints of this sort of projection. 
between these spaces, and become the basis of further selective projection into the blend. A generic space, which is the result of mapping that takes place between the input spaces, comprises the elements that are shared characteristics of both these spaces. A blended space, being considered the most important element of conceptual integration, is the space where the actual meaning emerges in the course of on-line processing. The whole process, called running the blend, is possible owing to three component processes, i.e. (i) composition, where elements of separate inputs are juxtaposed and connected with each other, (ii) completion, involving "unconscious and effortless recruitment of background frames" (Evans and Green 2006: 409), and (iii) elaboration, responsible for the production of structure unique to the blend, non-computable from the abovementioned spaces (cf. Evans and Green 2006). The unique nature of conceptual blending is best accounted for by Fauconnier and Turner (2002: 306):

Conceptual blending is not a compositional algorithmic process and cannot be modeled as such for even the most rudimentary cases. Blends are not predictable solely from the structure of the inputs. Rather, they are highly motivated by such structure, in harmony with independently available background and contextual structure. (...) In this regard, the most suitable analog for conceptual integration is not chemical composition but biological evolution.

The elements indicated above are known as constitutive processes of the integration theory. Equally important is the aspect vital relations, also responsible for successful blending and its creativity. Fauconnier and Turner enumerate the following vital relations: change, identity, time, space, cause-effect, part-whole, representation, role, analogy, disanalogy, property, category, similarity, intentionality and uniqueness (Fauconnier and Turner 2002: 93-102). ${ }^{3}$

What is more, to avoid vagueness and arrive at the most appropriate interpretation of the emergent meaning, the so-called

\footnotetext{
${ }^{3}$ Vital relations are accounted for in detail by Fauconnier and Turner themselves, as well as by other cognitivists (i.a. Evans and Green 2006, Libura 2007, 2010, Delibegović Džanic 2007). For the purpose of this paper, however, only those vital relations that appear in the course of the analysis will be thoroughly discussed.
} 
optimality, or governing principles, which restrict the whole integration, must be recalled. ${ }^{4}$ These are: the topology principle ("other things being equal, set up the blend and the inputs so that useful topology in the inputs and their outer-space relations is reflected by inner-space relations in the blend" (Fauconnier and Turner 2002:327)), the pattern completion principle ("complete elements in the blend by using existing integrated patterns as additional inputs" (ibid., 328)) the integration principle ("achieve an integrated blend" (ibid., 328)), the maximization of vital relations principle ("maximise vital relations in the network" (ibid., 330)), the web principle ("manipulating the blend as a unit must maintain the web of appropriate connections to the input space easily and without additional surveillance of composition" (ibid., 331)) the unpacking principle ("the blend all by itself should prompt for the reconstruction of the entire network" (ibid., 332)), and the relevance principle ("the element in the blend should have relevance for establishing links to other spaces and for running the blend" (ibid., 333)).

All principles as well as restrictions imposed on blending contribute to a more effective integration process. Once again, as pointed out by Fauconnier and Turner (2002: 92),

We do not establish mental spaces, connections between them, and blended spaces for no reason. We do this because it gives us global insight, human-scale understanding, and new meaning. It makes us both efficient and creative. One of the most important aspects of our efficiency, insight and creativity is the compression achieved through blending.

Having briefly discussed the basic theoretical assumptions of Fauconnier and Turner's theory, let us now proceed to the analysis of

\footnotetext{
${ }^{4}$ It has to be noted here that the introduction of optimality (or governing) principles was the Fauconnier and Turner's response to strong accusations from other cognitivists viewing CBT as an ad hoc theory. Coulson and Oakley, for instance notice that " $[\mathrm{CBT}]$ runs the risk of being too powerful, accounting for everything, and hence, explaining nothing" (2000:186, 192). Gibbs points out that Fauconnier and Turner's work is unable to "predict the [linguistic] behaviour in advance" as well as comments on the lack of "very conditions under which the hypothesis should (...) be evaluated" (2000: 349).
} 
a selected shock advertisement and uncover the nature of blending hidden behind such ads.

4. Conceptual Blending Theory in practice: an analysis

This part of the present study offers a conceptual blending analysis of a shock advertisement used in the social campaign for Organ Donor Foundation (source: www.odf.org.za). Before we tackle the problem, it has to be stated that the application of Conceptual Blending Theory to analyze any kind of advertisement, is rather limited, both among linguists and consumer researchers. Earlier attempts made upon the analysis of advertisements in the light of cognitive semantics concerned the function of analogy and metaphor in advertising (cf. Scott 1994, McQuarrie and Mick 1996, 1999), or a limited description of the cognitive mechanism of the blending theory while accounting for aesthetic experiences in museums (Joy and Sherry 2003, after Joy et al. 2009). The first thorough study of various advertisements viewed from a conceptual blending perspective was proposed by Vanessa Nühnen in her 2009 seminar work, where she stresses the ubiquity of blending processes in print media, television, outdoor and viral advertising, as well as points to the role of the beholder who reads out and decodes hidden nuances of integration (cf. Nühnen 2009).

A shock advertisement that is going to be analysed in the light of Conceptual Blending Theory was released in 2012 by the Organ Donor Foundation (source: www.adsoftheworld.com). It depicts the image of a parachutist who did not survive the fall from high altitude. The parachutist lies on the grass in the forest, surrounded by seven bodies, all wearing white garments. Apart from the visual image there is also a verbal message which says: "if you are not an organ donor when you die, you take someone else with you". The advertisement is presented in Figure 2. 


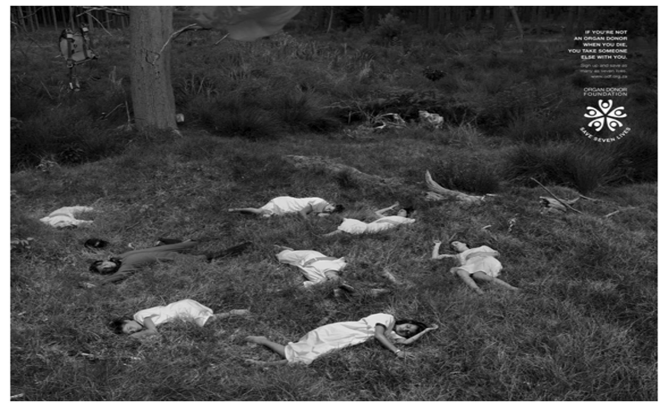

Figure 2. The advertisement for the Organ Donor Foundation (available at: www.adsoftheworld.com)

The general message of the shock advertisement has the chance to be successfully decoded only if we allow for two inextricably bound components, i.e. its visual representation, and verbal support. The slogan used here facilitates the overall understanding of the message, and makes the content of an ad more transparent for the reader, thus allowing him to avoid a multitude of other interpretations associated with the image itself. Assuming, after Fauconnier and Turner, that a complete "understanding [of a complex message] demands both its intuitive apprehension as a whole and its detailed proof broken down into a series of steps" (Fauconnier and Turner 2002: 284), let us proceed towards the reconstruction of the emergent meaning. Adopting Fauconnier and Turner's basic integration network, two input spaces must be recalled, i.e. the parachutist space, which constitutes input space 1 , and the patient space, being input space 2 . The elements that appear in the parachutist space, indispensable to derive the blend, point to selected aspects connected with the parachutist: first, we deduce what his occupation, or hobby, was by associating a parachute which hangs on the tree with the body in a uniform lying on the grass. What is more, it is possible to indicate the parachutist's age activating the general frame of parachuting which recalls physically fit people performing such an activity at a very 
young age. Input space 1, being supported with the slogan, points to the parachutist not being registered as an organ donor.

Input space 2 is the patient space, and provides information concerning the terminally ill awaiting organ donation. The image depicts seven dead bodies scattered all over the grass, each dressed in white hospital outfit. They symbolize patients who waited for the organ transplantation but failed to be operated on due to the lack of organs to be donated. The reconstruction of the necessary components comprised in input spaces, as well as vital relations that occur as the result of cross-space mapping are illustrated in Figure 3.

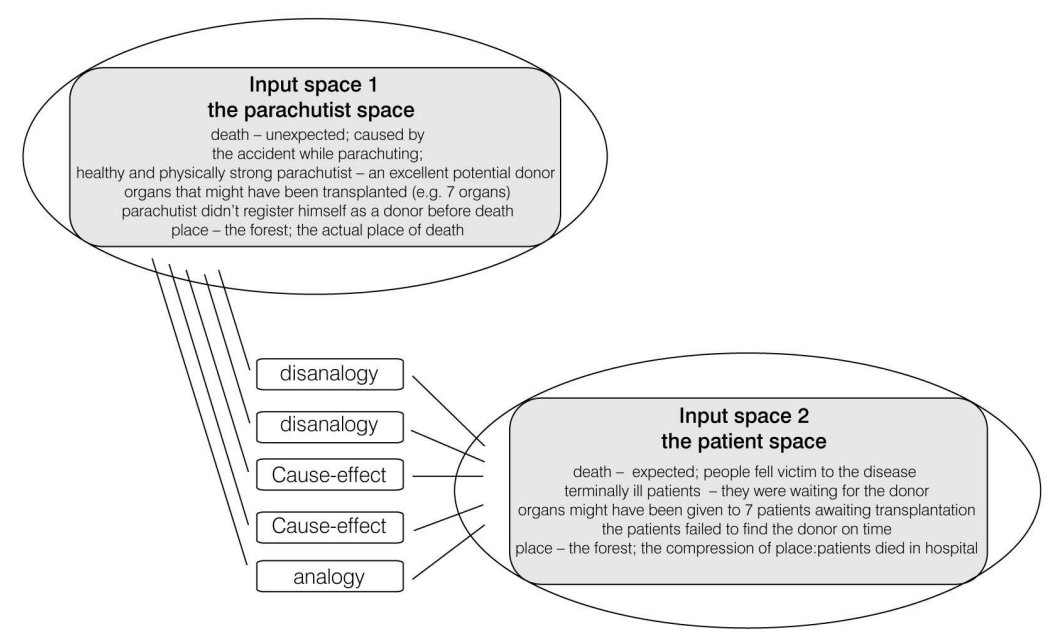

Figure 3. The parachutist space and the patient space

Analyzing the above figure, it can be noticed that relevant parts from both input spaces are matched on the basis of various relations that occur during the composition process. The relation of disanalogy 
is visible in two cases: expected vs. unexpected death, and in case of healthy vs. terminally ill people. A vital relation of cause-effect links both instances of death: if the parachutist had registered himself as an organ donor before his death he might have saved the lives of others, thus allowing doctors to transplant his healthy organs. Of particular importance is the number of dead bodies wearing white garments. Recalling a 'background frame' (Fauconnier and Turner 2002), which is a recent knowledge in transplantation, it is known that doctors are able to transplant up to seven organs: heart, kidneys, pancreas, liver, and lungs ${ }^{5}$, which corresponds with the number of dead patients. The colour of patients' clothes is also vital: the white colour is the symbol of innocence and purity, which might be indicative of patients' helplessness in the wake of an illness they fell victim to.

The generic space, which aims at eliciting shared characteristics of the input spaces, presents the following common elements: the notion of death, as well as the notion of place, i.e. the forest ${ }^{6}$.

The most important element of the network model is the blended space where a new meaning emerges as a result of unusual fusion of visual and verbal element, i.e. a drastic image of a parachutist and scattered bodies, and a slogan, respectively. This visual-verbal fusion is additionally supported with the elements from both input spaces, selectively projected into the blended space. Thus, the emergent structure becomes deducible within the blend, allowing for a new structure being the result of visual-verbal fusion, and involving the amalgamation of the patient and parachutist space. The abovementioned parameters obtained are the result of the so-called composition process. The next step in creating the meaningful conceptual blend is completion, expressed here by recalling background frames associated with an ad. To successfully arrive at the intended meaning, at least four frames must be activated, i.e. the

\footnotetext{
${ }^{5}$ The information used above is available at: www.odf.org.za.

${ }^{6}$ In case of the patient space we are dealing with the compression of place assuming that patients suffering from terminal illnesses usually die in hospitals rather than in the forest.
} 
donation frame, the transplantation frame, the ethics frame and the altruism frame. The final process, known as elaboration, or running the blend, allows us to infer the actual meaning that occurs in the emergent structure; this usually happens at the point during which the recipient of the information is able to decode true intentions of such an ad. Therefore, a real message conveyed in a shock ad is to encourage people to become organ donors and make them more aware to what extent this life-saving attitude is worth considering in the wake of a multitude of incurable diseases these days. A detailed integration network of a discussed instance is presented in Figure 4. 


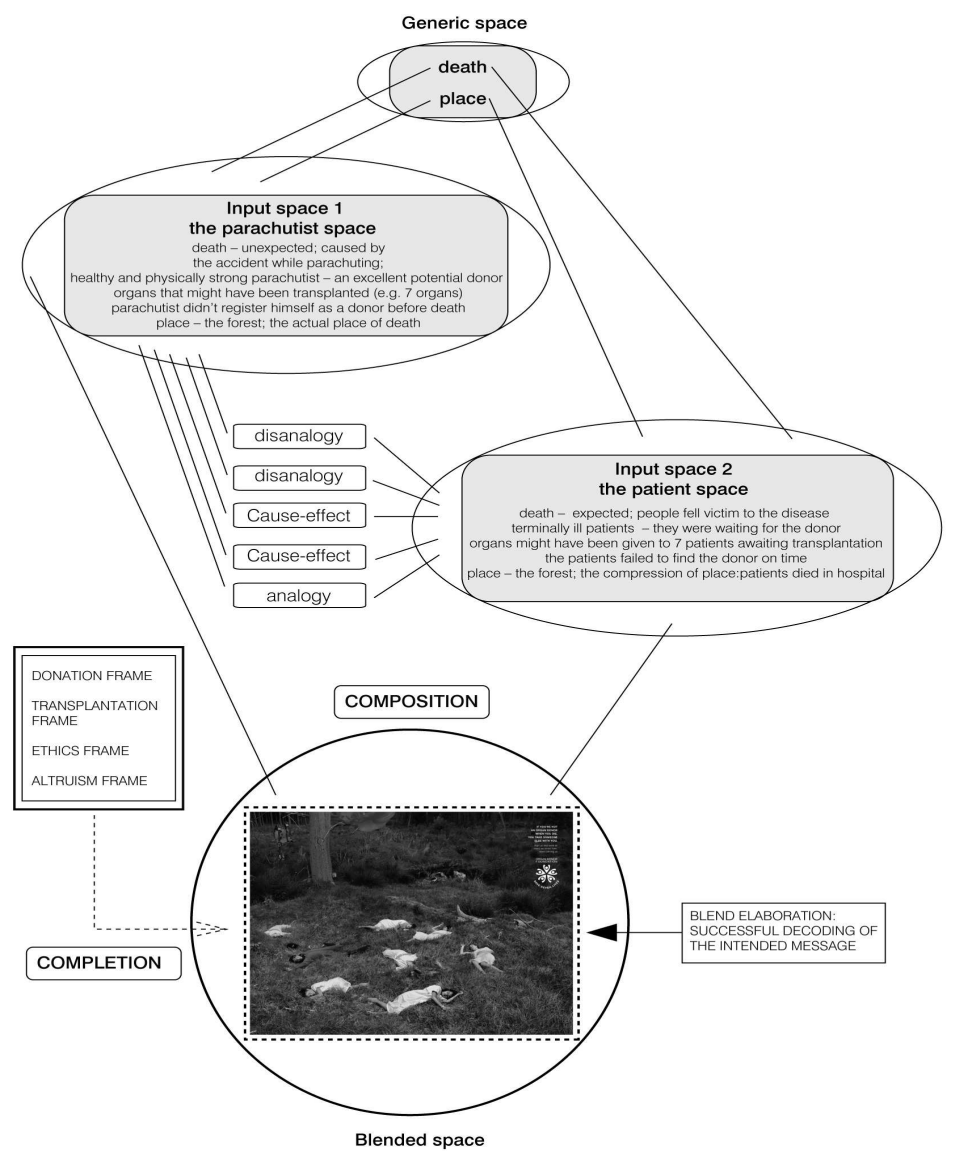

Figure 4. An integration network model of the analyzed shock ad

5. Conclusions

As indicated in the analysis proposed in this paper, shockvertising offers enormous interpretive possibilities due to its hybrid nature, being usually the juxtaposition of drastic images and blunt slogans. Each of these elements plays a vital role in decoding the general 
message hidden in the conceptual blend, if we are to approach shock advertisements using the tools of Fauconnier and Turner's theory.

As we have seen, Conceptual Blending Theory fully meets the requirement of 'on-line' contextual interpretation of such ads, pointing to their dynamicity and situational context. However, the nature of interpretive processes is more complex and requires greater cognitive effort from the recipient of a shock advertisement, since it is not only a combination of totally different input spaces but also a recollection of visual images and verbal messages superimposed while decoding the emergent meaning. Hence, an important role should be ascribed to the beholder who uses blending processes to make sense of what is not explicitly stated in such ads.

\section{References}

Arnold, C. 2009. A punch in the face can offend. (Retrieved from Lexis Nexis database).

Belch, G. E. and M. A. Belch. 1998. Advertising and promotion: an integrated marketing communications approach. New York: McGraw-Hill.

Berger, W.2001. Advertising today. London: Phaidon.

Cornelissen, J. 2006. Making sense of theory construction: metaphor and disciplined imagination. In: Organ Stud 27(1). 1579-1597.

Coulson, S. and T. Oakley. 2000. Blending basics. In: Cognitive Linguistics 11(3/4).175-196.

Dahl, D. W. et al. 2003. Does it pay to shock? Reactions to shocking and nonshocking advertising content among university students. In: Journal of Advertising Research 43. 268-280.

Delibegović Džanić, N. 2007. Conceptual Integration Theory - the key for unlocking the internal cognitive choreography of idiom. In: Linguistics (Jezikoslovlije) 8 (2). 169-191.

Evans, V. 2007. A glossary of cognitive linguistics. Edinburgh: Edinburgh University Press.

Evans, V. and M. Green. 2006. Cognitive linguistics: an introduction. Edinburgh: Edinburgh University Press.

Falk, P. 1997. The Benetton-Toscani effect: taking the limits of conventional advertising. In: M. Nava, A. Blake, I. MacRury and B. Richards (eds.) Buy this book: studies in advertising and consumption. New York: Routledge. 64-83.

Fauconnier, G. 1994. Mental spaces, Cambridge: MIT Press. 
Fauconnier, G. 1997. Mappings in thought and language. Cambridge: CUP.

Fauconnier, G. 2010. Ten lectures on cognitive construction of meaning by Gilles Fauconnier. Beijing: Foreign Language Teaching and Research Press.

Fauconnier, G. and M. Turner. 1998. Conceptual Integration Networks. In: Cognitive Science 22 (2). 133-187.

Fauconnier G. and M. Turner. 2002. The way we think: conceptual blending and the mind's hidden complexities. New York: Basic Books.

Grady, J., Oakley, T. and S. Coulson. 1999. Blending and metaphor. In: Steen, G. and R. Gibbs (eds.) Metaphor in cognitive linguistics. Philadelphia: John Benjamins. 234-246.

Joy, A. and J. Sherry. 2003. 'Speaking of art as embodied imagination: a multisensory approach to understanding aesthetic experience'. In: J Consum Res 30. 259-284.

Joy et al. 2009. Conceptual blending in advertising. Journal of Business Research 62. 39-49.

Konieczna, A. 2010. Szok narzędziem kampanii spotecznych. Problemy zarzadzania wspótczesna firma - teoria i przyktady. Wrocław: Wydawnictwo Uniwersytetu Ekonomicznego we Wrocławiu.

Kubacka, N. 2012. There are no shocking pictures,only shocking reality. Oliviero Toscani. The power and role of Benetton's shockvertising. Thesis written in Centria University of Applied Sciences, the Ylivieska Unit (Degree Programme in Industrial Management). (available at: www.theseus.fi )

Lakoff, G. and M. Johnson 1980. Metaphors we live by. Chicago: UCP.

Leech, G.N. 1972. English in advertising: a linguistic study of advertising in Great Britain. In: English Language Series. London: Longman.

Libura, A. 2007. Amalgamaty kognitywne w sztuce. Kraków: Universitas.

Libura, A. 2010. Teoria przestrzeni mentalnych i integracji pojęciowej: struktura modelu i jego funkcjonalność. Wrocław: Wydawnictwo Uniwersytetu Wrocławskiego.

Longman, K., E. 1971. Advertising. New York: Harcourt Brace Jovanovich Inc.

McQuarrie E. and D.G. Mick. 1996. Figures of rhetoric in advertising language. In: $J$ Consum Res 22. 424-437.

McQuarrie E. and D.G. Mick. 1999. Visual rhetoric in advertising: text- interpretive, experimental, and reader response analysis. In: J Consum Res 26. 37-54.

Nühnen, V. 2010. Conceptual Blending in advertisements. Seminar paper. Justus Liebzig University Giessen.

Parry, S., Jones, R., Stern, P. and M. Robinson. 2013. 'Shockvertising': An exploratory investigation into attitudinal variations and emotional reactions to shock advertising. In: Journal of Consumer Behaviour. Special Issue: Challenges to Attitude and Behaviour Change Through Persuasion, 12 (2). 112-121. 
Sandikçi, O. 2011. Shock tactics in advertising and implications for citizen-consumer. In: International Journal of Humanities and Social Science Vol. 1 (18). 42-50.

Scott, L. 1994. Images in advertising: the need for a theory of visual rhetoric. In: $J$ Consum Res 1994 (21). 252-274. 